\title{
EMBRYOLOGY OF Triatoma infestans (KLUG), (HEMIPTERA, REDUVIIDAE), A CHAGAS'DISEASE VECTOR
}

\begin{abstract}
SUMMARY
This study reports the embryogenesis of T. infestans (Hemiptera, Reduviidae). Morphological parameters of growth sequences from oviposition until hatching (12-14 $\mathrm{d} 28^{\circ} \mathrm{C}$ ) were established. Five periods, as percent of time of development (TD), were characterized from oviposition until hatching. The most important morphological features were: 1) formation of blastoderm within $7 \%$ of TD; 2) germ band and gastrulation within $30 \%$ of $\mathrm{TD} ; 3$ ) nerve cord, limb budding, thoracic and abdominal segmentation and formation of body cavity within $50 \%$ of TD; 4 ) nervous system and blastokinesis end, and development of embryonic cuticle within $65 \%$ of TD; 5) differentiation of the mouth parts, fat body, and Malphigian tubules during final stage and completion of embryo at day 12 to day 14 around hatching. These signals were chosen as appropriate morphological parameters which should enable the evaluation of embryologic modifications due to the action/s of different insecticides.
\end{abstract}

KEY WORDS: Insects, Triatominae, embryology.

\section{INTRODUCTION}

Chagas'disease remains one of the most serious public health problems in Latin America. Unfortunately, there is neither efficient nor widely accepted prophylaxis in the control of the vector in houses, and, the search for appropriate chemical agents - phosfored, piretroids, juvenoids and synthetic juvenile hormone analogs (JHA) - is still necessary.

Although the embryology of insects is well known, studies on Triatominae are very scarce. Recently, studies were performed on the development of the nervous system in $T$. infestans in relation with the application of organophosfored insecticides? ${ }^{7}$. Furthermore, it was shown that the application of Juvenile Hormone $(\mathrm{JH})$ and JHA over $\mathbf{T}$. infestans and $\mathbf{R}$. prolixus eggs provoke a disruption on the development of these insects ${ }^{8-11}$.

The study of T. infestans' embryologic development constitutes an obligate step in order to increase the efficacy in the production and application of different ovicidal compounds.

The aim of this work is to contribute to the knowledge of the embryology of this Hemipteroid insect. It reports on the morphological stages of the insect and establishes well defined parameters which will allow, in future studies,

(1) Instituto Nacional de Diagnóstico e Investigación de la Enfermedad de Chagas "Dr. M. Fatala Chaben". Av. Paseo Colón, 560. 1432. Buenos Aires, Argentina.

(2) Research associate of CONICET. 
FICHERA, L. E. \& RIARTE, A. - Embryology of Triatoma infestans (KLUG), (Hemiptera, Reduviidae), a Chagas'disease vector. Rev. Inst. Med. trop. S. Paulo, 34(3): 211-216, 1992.

the evaluation of morphological modifications due to the action/s of different JHA.

\section{MATERIAL AND METHODS}

Eggs to Triatoma infestans were obtained and maintained at $28^{\circ} \mathrm{C}$ and $50 \%$ of humidity in the rearing colony of the Institute Fatala Chaben. They were selected at different periods from oviposition until hatching. With the object of exactly determining time zero, oviposition was carefully monitored.

One hundred and ten eggs were processed within $3 \mathrm{hs}$ and 14 days after oviposition according to PICOLLO ${ }^{7}$ with modifications carried out in our laboratory. They were fixed in ethil eter vapor and Bouin solution for 60 minutes, and the eggs were kept for $24 \mathrm{hs}$ in the fixing solution. They were dehydrated with ethanol $90^{\circ} \mathrm{C}$ for 2 days; the chorion was extracted and the eggs were immersed in ethanol of increasing strength for different periods. The embryos were included in paraffin under stereoscopic microscopy at different planes, sectioned in 5 um slices, up to the end of the sample and stained with Hematoxylin \& Eosin. The developmental stages were expressed as a percentage of total developmental time, according to BENTLEY et $\mathrm{al}^{1}$. In T. infestans, $100 \%$ corresponds to 14 days of development.

\section{RESULTS}

It has been shown that at oviposition, the egg of Triatoma infestans, is slightly flattened on the dorsal side and covered by the chorion, a tough shell, beneath which is the vitelline membrane. After oviposition, the different stages were characterized, by means of histologic studies, throughout the embryologic development.

\section{Inicial stage to $7 \%$ of development $n=29$}

At oviposition the egg was characterized by the periplasm at the surface, and an internal protoplasmic reticulum in which the yolk is inmersed. In eggs of $3 \mathrm{hs}$, a vitelline membrane surrounded a fine zone of granular periplasm. The energids migrated toward the periphery of the egg to form a syncytio-layer with cells lacking defined cytoplasmatic borders, and some remai- ned in the yolk to form the vitellophags ${ }^{1}$. Later, in eggs of $22 \mathrm{hs}$, this layer acquired distinct cell walls and constituted the blastoderm or primary epithelium (Fig. 1).

\section{Up to $28 \%$ of development $(n=21)$}

The blastula and gastrula were completed during this period. The blastoderm was thickened along the ventral zone of the egg forming the germ band. Later, gastrulation took place and the differentiation of the lateral plates gave rise to the future ectoderm. The inner layer evolved into the medial plate and the lateral bands, which would constitute the mesoendoderm (Fig. 2). In eggs of $60 \mathrm{hs}$ the embryonic layers were already defined; the embryo was in contact with the yolk mass while the extraembrionic ectoderm had initiated the development of the extraembrionic membranes (Fig. 3).

The tissue formed at the edge of the germ band, folded ventrally to give rise to the amniotic folds; these fused in the ventral midline to form the amnios that enclosed the amniotic cavity; the outer surface constituted the serosa.

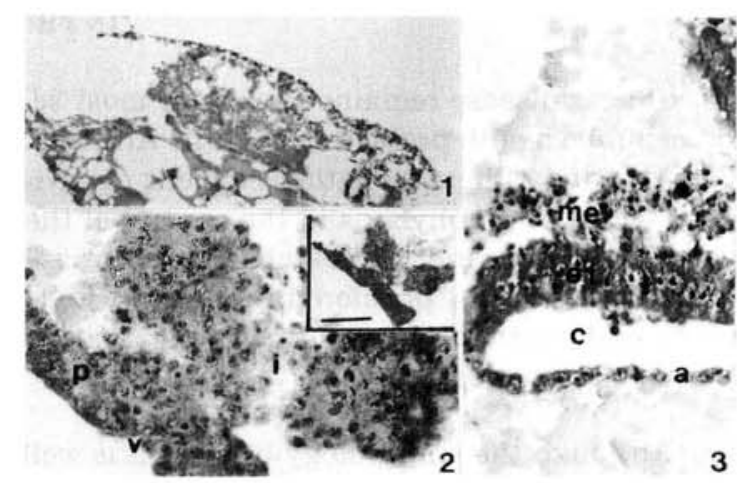

Fig. 1 - Initial formation of the blastoderm, sincytio layer shown in egg of 22 hs. H \& E x 63.

Fig. 2 - Gastrulation. The lateral plates (p), ectoderm of germ band, ventral groove (v), and inner layer (i) shown in an egg of this period. H \& E x 400 .

Insert. Panoramic view of the rudimentary embryo. Scale bar $=0.1 \mathrm{~mm}$. H \& $\mathrm{E} \times 60$.

Fig. 3 - Differentiation of ectoderm (et), mesoendoderm (me) and initial development of extraembryonic ectoderm, the am nios (a), and amniotic cavity (c) shown in embryo of $60 \mathrm{hs}$ H \& E x 400 . 
FICHERA, L. E. \& RIARTE, A.-Embryology of Triatoma infestans (KLUG), (Hemiptera, Reduviidae), a Chagas'disease vector. Rev. Inst. Med. trop. S. Paulo, 34(3): 211-216, 1992.

\section{Up to $50 \%$ of development $(n=25)$}

During this period the embryo was elongated and became broader; after its invagination the inner layer was segmented forming the middle cord and lateral strands, symetrically placed, and lining the ectoderm. Embryos of 5 days, in a longitudinal plane, showed gnatal, thoracic and abominal segmentations and ectodermic invaginations corresponding to presumptive estomodeum and proctodeum (Fig. 4). At the same time, in transversal planes, the mesodermic outlines of the embryo, covered by the ectoderm, showed the somites and rudimentary celomic sacs bound to the yolk and remaining open to the epineural sinus. Later, they became confluent, forming the primary body cavity (Fig. 5). In addition, the neuroblasts, began to proliferate, the nervous cord was formed along the midventral longitudinal line, developing later into the paired nerve strands.
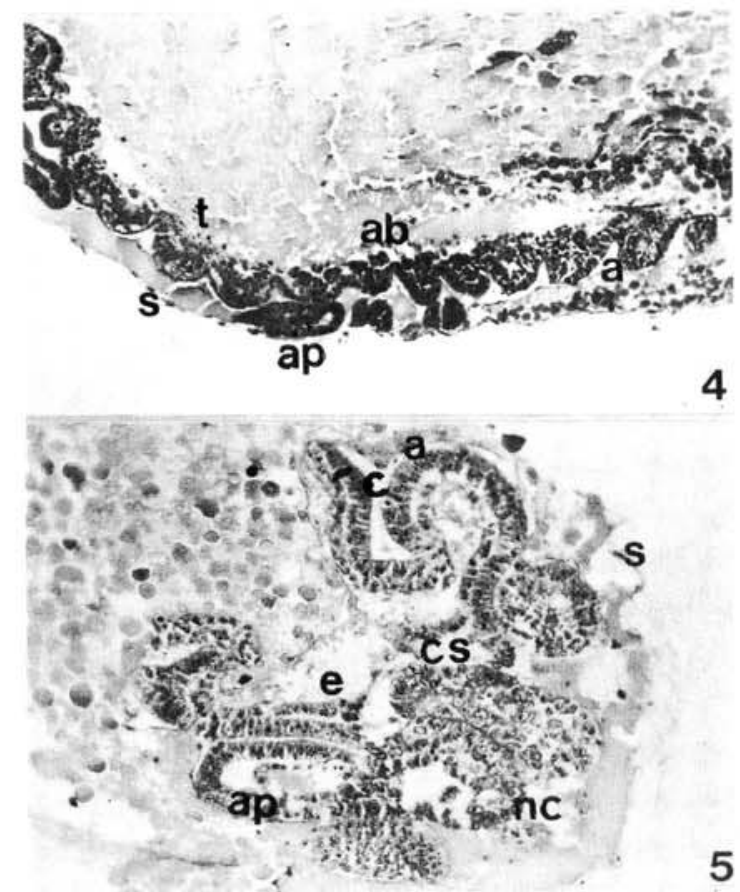

4

Fig. 4 - Longitudinal section of $5 \mathrm{~d}$ embryo surrounded by amnios (a) and serosa (s). Presence of appendages (ap) and thoracic (t) and abdominal (ab) segmentations. H \& E x 100. Fig. 5 - Transversal section of a 5 d embryo immersed in amniotic cavity (c) and surrounded by amnios (a) and serosa (s). Development of the rudimentary celomic sacs (cs), epineural sinus (es), the nervous cord (nc) and appendages (ap). $\mathrm{H}$ \& $\mathrm{E} \times 160$.
The neuropile of the ganglia and differentiated neurons were observed in 7 day old embryos (Fig. 6). At the same time the embryo clearly showed three pairs of legs and nine abdominal segments (Fig. 7) and was still immersed in the yolk (Fig. 8). At the end of this period the blastokinesis, - the migration of the embryo, - was initiated.

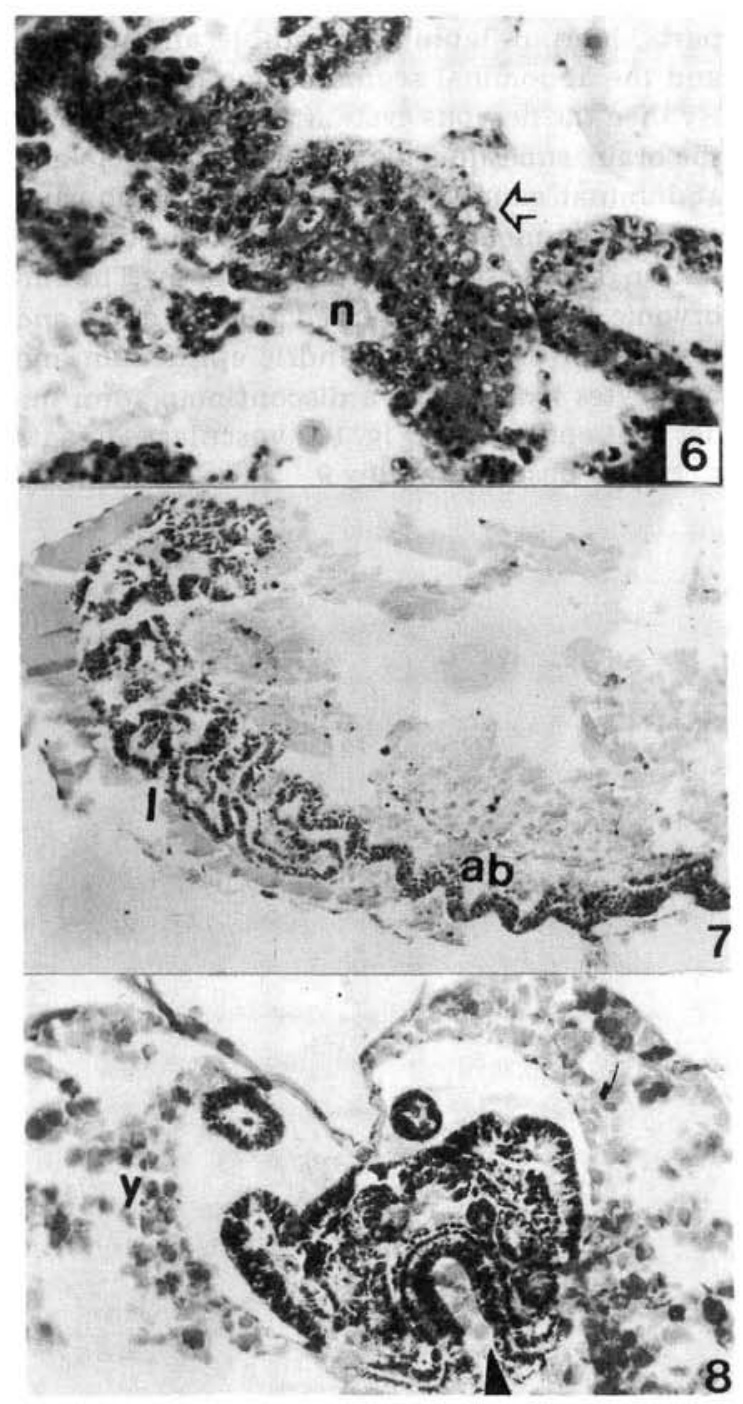

Fig. 6-Neurons ( $\longrightarrow$ ) and neuropila (n) observed in higher magnification of the nervous cord of $7 \mathrm{~d}$ embryo. H \& E x 400.

Fig. 7 - Longitudinal section of $7 \mathrm{~d}$ embryo showing three pairs of legs (1) and abdominal (ab) segmentations. H \& E x 100.

Fig. 8 - Transversal section of $7 \mathrm{~d}$ embryo showing the immersion of the embryo into the yolk (y) previous to blastokinesis and the ectodermic invagination corresponding to the estomodeo $(\longrightarrow)$. H \& E x 160 . 
FICHERA, L. E. \& RIARTE, A. - Embryology of Triatoma infestans (KLUG), (Hemiptera, Reduviidae), a Chagas'disease vector. Rev. Inst. Med. trop. S. Paulo, 34(3): 211-216, 1992.

\section{Up to $64 \%$ of development $(n=13)$}

When these movements were completed, at day 9 , the embryo revolved the surface, embracing the yolk which remained in the developing mid-gut lumen. A thin dorsal wall constituted the dorsal closure formed by the extraembryonic membranes, later replaced by the true dorsal ectoderm. At this time, following blastokinesis the head showed specialization of the mouth parts, labrum, labium, mandible and maxilla and the abdominal segmentation disappeared. By then the nervous system was constituted by the brain, subesophagic and fused thoracic and abdominal ganglia (Fig. 9). The hypopharinx and the rudiments of gut continued the differentiation process surrounded by fat body. The embryonic cuticle was observed at day 8 and 9 and it was represented by cilindric epithelium and oenocytes localized in a discontinous form under that epithelium (Fig. 10); vascular elements were also observed at day 9 .
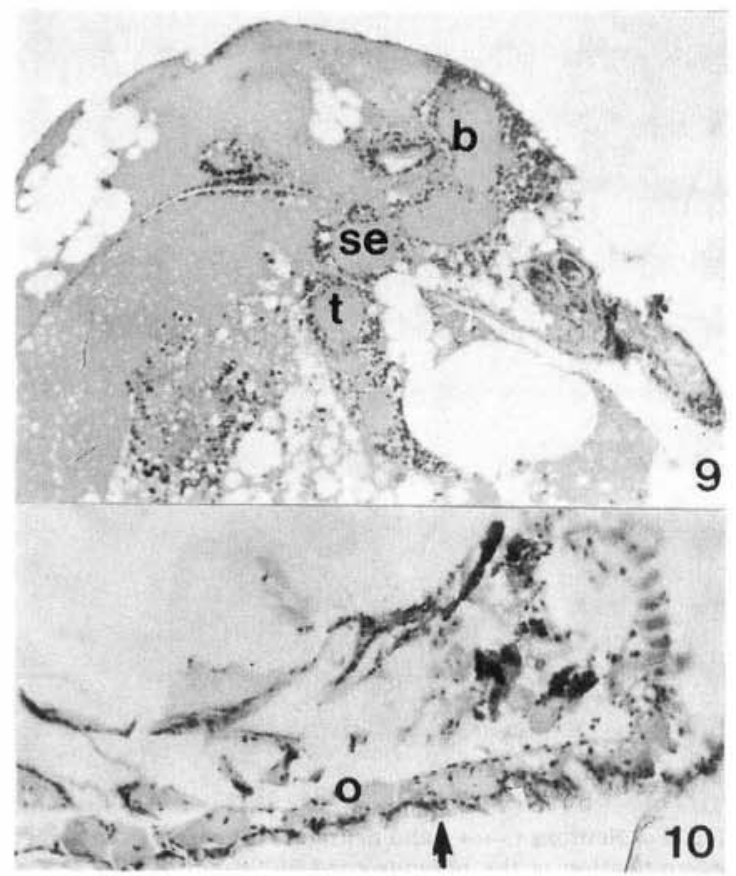

Fig. 9 - Details of $9 \mathrm{~d}$ embryo showing the total development of the nervous system constituted by brain (b), subesophagic (se) and fused thoracic (t) and abdominal ganglia. $\mathrm{H}$ \& E x 100 .

Fig. 10 - The embryonic cuticle in $10 \mathrm{~d}$ embryo is constituted by the oenocytes $(0)$ and the cilindric epithelium $(\longrightarrow) . \mathrm{H}$ \& $\mathrm{E} \times 160$.

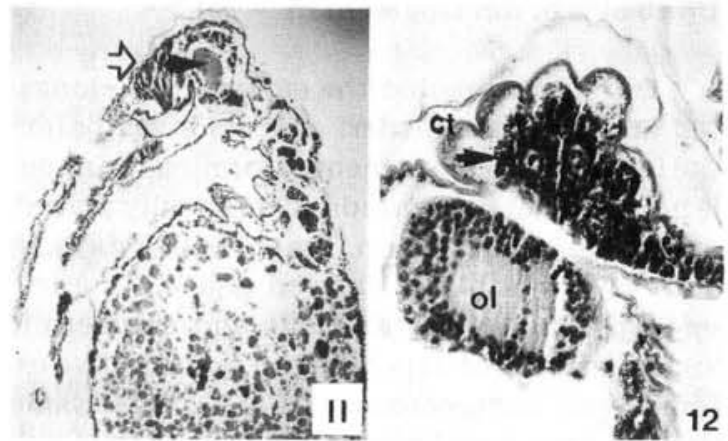

Fig. 11 - Panoramic aspect of 12 d embryo previous to hatching. The head shows the development of mouth parts, the muscle $(\longrightarrow)$, the optical lobe $(\longrightarrow$ ), the farinx (fx) and thorax regions. H \& E x 63.

Fig. $12-$ Details of the eye $(\longrightarrow)$ showing the ommatidials covered by cuticle (ct), the brown pigment and the optical lobe (ol). H \& E x 400 .

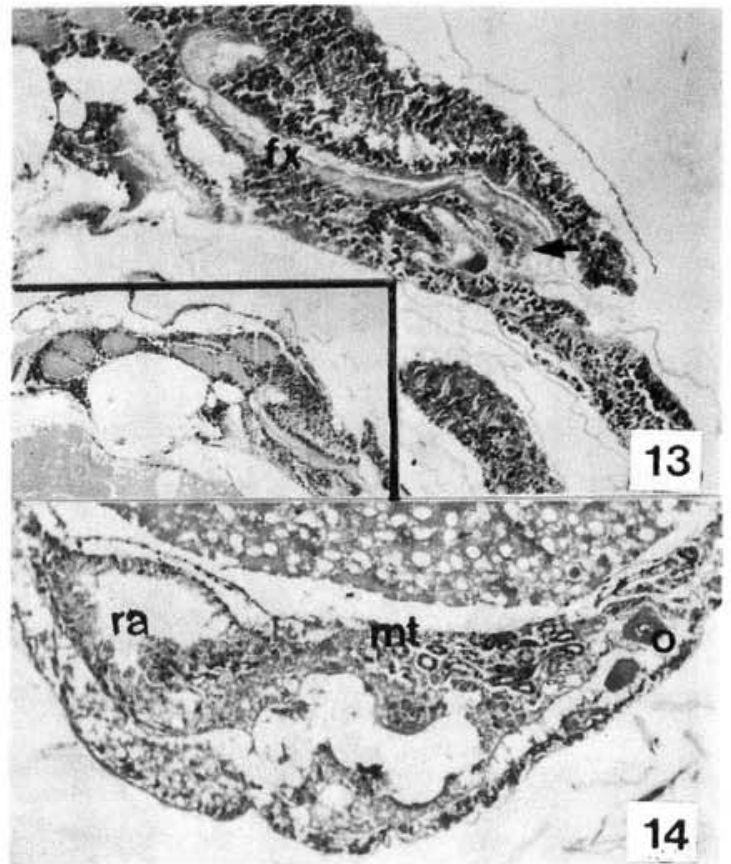

Fig. 13 - Higher magnification of farinx covered by cuticle. Insert. Panoramic view of nervous system and its relationship with the initial part of digestive tube, the farinx (fx). H \& $\mathrm{E} \times 160$.

Fig. $14-$ Embryo of $12 \mathrm{~d}$ showing the end of the digestive tube, the rectal ampulla (ra) closely associated to sections of Malpighian tubules (mt). Oenocites (o) are located under the epithelium. H \& E x 160 
FICHERA, L. E. \& RIARTE, A. - Embryology of Triatoma infestans (KLUG), (Hemiptera, Reduviidae), a Chagas'disease vector. Rev. Inst. Med. trop. S. Paulo, 34(3): 211-216, 1992.

Up to end of development $\mathrm{n}=22$

The completion of the differentiation process of tissues and organs was achieved around day 10. Thus, during this period the shape was defined and the head, claws, mouth parts, and segmentation of the thorax were completed. In $12 \mathrm{~d}$ embryos the muscles were well differentiated as evidenced in the head and the mouth parts (Fig. 11). The compound and pigmented eyes showed the ommatidial which were separated from each other by narrow areas of cuticle; this structure was directly related to the optical lobe (Fig. 12). The pharinx was lined by cuticle, as well as the rectal ampulla, located at the posterior end of the hindgut, which showed a folded glandular epithelium (Fig. 13). At this time the urinary system represented by Malpighian tubules constituted a plexiform network which surrounded the rectal ampulla (Fig. 14). A complete embryo was observed at day 14 close to hatching.

\section{DISCUSSION}

This work characterizes defined stages of the embryology of $T$. infestans, specifically the development of different tissues and organs in chronological periods.

Reports on the embryologic development of hematophagous Reduviidae, of medical importance are scarce, however that of other Hemiptera as Oncopeltus fasciatus Dall and Pyrrhocoris apterus $\mathrm{L}^{3}$ have been described. It was shown that the shape of the primordium in embryos belonging to this order is variable ${ }^{4}$, and that the growth of the germ band is produced by immersion into the yolk.

These observations are in accordance with our findings showing that the embryonic rudiment of Triatoma infestans is small in relation to the egg and that the ventral side of the germ band increases in size towards the yolk. After blastokinesis the embryo revolved to the surface and the yolk then lied inside in the future mid gut lumen. We have observed that the embryo of $\mathbf{T}$. infestans secretes a cuticle soon after blastokinesis which seems to be separated from the epidermis and left in its place. It has been suggested in different species of Orthoptera that a
- new cuticle proper is formed, and stands as the second embryonic cuticle ${ }^{1,2,5}$.

Our results show that the sequence of the most relevant morphological features in the embryology of $\mathbf{T}$. infestans are blastoderm formation at $22 \mathrm{hs}$, development of the germ band and gastrulation within 60 hs to $72 \mathrm{hs}$ and formation of embryonic layers, ectoderm and mesoendoderm, and extraembryonic membranes at the end of the period. Between 5 th and 7 th $d$ the embryo shows the somites, body cavities and the cephalic, thoracic and abdominal segmentation, the appearing of the nervous structures and the beginning of the blastokinesis. During 8 th to 9 th days ends the blastokinesis, the specialization of the mouth parts is evident, the nervous system is completed and the embryonic cuticle begins to form. On $d 10$ and onward, the muscle tissue, fat bodies, and Malpighian tubules differentiate, and the maturity of the embryo is completed by hatching time on days 12 to 14.

In order to evaluate the action of $\mathrm{JH}$ and JHA or other ovicides, these morphological features constitute very distinct and standard parameters in the embryologic development of $T$. infestans. Based on these findings the potential embryological modifications due to the action/s of bioregulators and other insecticides could be evaluated. In fact, preliminary results of work performed in our laboratory with metoprene, a JHA, on T. infestans eggs, have shown $70 \%$ of inhibition of embryologic development, small size of the embryo and uncompleted blastokinesis.

The susceptibility of eggs to phosphorated insecticides has been reported in $T$. infestans ${ }^{8,}$ ? and the relationship between the development of the nervous system to the colinesterasic system has been described. In addition, treatment of the Chagas'disease vector with JHA would diminish its susceptibility to T. cruzi infection ${ }^{6}$.

A combined strategy including housing improvement, health education, community participation, should then be associated to actions on the vector and on its eggs, to achieve an efficient control of Chagas'disease. 
FICHERA, L. E. \& RIARTE, A. - Embryology of Triatoma infestans (KLUG), (Hemiptera, Reduviidae), a Chagas'disease vector. Rev. Inst. Med. trop. S. Paulo, 34(3): 211-216, 1992.

\section{RESUMEN}

Embriología del Triatoma infestans, vector de la enfermedad de Chagas.

En este estudio se caracterizó el desarrollo embrionario del T. infestans (Hemiptera Reduviidae). Se establecieron parámetros morfológicos secuenciales de crecimiento desde la oviposición hasta la eclosión, (12-14 d 28 $\left.{ }^{\circ} \mathrm{C}\right)$. Cinco períodos de crecimiento fueron determinados $\mathrm{y}$ expresados como fracciones porcentuales del tiempo total del desarrollo (TD) hasta la eclosión. Los eventos morfológicos mas importantes fueron: 1) La formación del blastodermo hasta el 7\% del TD; 2) La aparición de la banda germinativa y su gastrulación transcurridos un $30 \%$ del TD; 3) El comienzo de la formación del cordón nervioso, de las extremidades, la segmentación torácica y abdominal y la formación del mixocele cuando la embriogénesis alcanzó el 50\% del TD; 4) La terminación de la blastoquinesis, el desarrollo completo del sistema nervioso y la aparición de la cutícula embrionaria hasta el $65 \%$ del TD; 5) En la etapa final de la embriogenesis se observó la diferenciación del aparato mandibular, el cuerpo graso, los tubos de Malpighy. El embrión completa su organogénesis entre los 12 y 14 días. Estos parámetros morfológicos fueron seleccionados para evidenciar potenciales modificaciones embriológicas debidas a la acción ovicidas de diferentes insecticidas.

\section{ACKNOWLEDGMENT}

We wish to express our thanks to Dr. M. Carlomagno for her critical review of this manuscript and the English version. To Dr. C. Del Prado for his invaluable help of the photographs.

Support in part by Ministerio de Salud y Acción Social and by Secretaría de Ciencia y Tecnica of Argentina.
REFERENCES

1. BENTLEY, D.; KESHISHIAN, H.; SHANKLAND, M. \& TOROIAN-RAYMOND, A. - Quantitative staging of the embryonic development of the grasshopper, Schistocerca nitens. J. Embriol, exp. Morph., 54: 47-74, 1979.

2. CHAPMAN, R. F. - Insects, Structure and Function. In HODDER \& STORGHTON, ed. Embryology. London, 1983. v. 18 , p. $406-431$.

3. JOHANNSEN, O. A. \& BUTT, F. H. - Embryology of Insects and Myriapods. New York. McGraw Hill, 1941.

4. KUME, M. \& DAN, K. - Invertebrate Embryology, KU ME, M. \& K. DAN, ed. Embryonic Development, HASSEIGAKN, 20: 537-562, 1968.

5. MICCIARELLI, A. S. \& SBRENNA, G. - The embryonic apolyses of Schistocerca gregaria (Orthoptera). J. Insect. Physiol., 18: 1027-1037, 1972.

6. PERLOWAGORA-SZUMLEWICZ, A.: PETANA, W. B. \& FIGUEIREDO, M. J. - The evaluation of host efficiency and vector potential of laboratory juvenilized vectors of Chagas'disease. Effects of developmental changes induced by juvenile hormone analogues. In: Panstrongylus megistus (Hemiptera, Reduviidae) on the susceptibility of the insects to gut infection with T. cruzi. Rev. Inst. Med. trop. S. Paulo, 17: 97-102, 1975.

7. PICOLLO de VILLAR, M. I. - Caracterización del desarrollo embrionario de $T$. infestans (vinchuca) y su relación con los fosforados. Argentina, 1979 (Tesis. Univ. Nac. de Buenos Aires)

8. PICOLLO de VILLAR, M. I.; SECCACINI, E.; FONTAN, A. \& ZERBA, E. - Activity of the insect regulator Fenoxycarb (RO-13-5223) on Triatoma infestans (Hemiptera). Comp. Biochem Physiol, 87C: 367-370, 1987.

9. RODRIGUEZ, J. B.; GROS, E. G. \& STOKA, A. M. "Synthesis and activity of juvenile hormone analogues (JHA)". Z. Naturforc., 43: 1038, 1988.

10. RODRIGUEZ, J. B.; GROS, E. G. \& STOKA, A. M. "Synthesis and activity of juvenile hormone analogues (JHA) part II. Z. Naturforc., 44 b: $\mathbf{9 8 3 ,} 1989$.

11. STOKA, A. M. - Disruption of development on Triato minae bugs by action of juvenile hormone analogues. Rev. argent. Microbiol., 20(Supl): 86-90, 1988.

Recebido para publicação em 25/10/1991. Aceito para publicação em 31/03/1992. 